\title{
The Philippines at the Cortes de Cádiz
}

This article analyzes the participation of the Philippines in the Cortes de Cádiz, the parliament that, from 1810 to 1812, joined representatives of all territories of the Spanish empire for the first and only time. It explains the process through which the Philippines came to have parliamentary representation; the election of Ventura de los Reyes as the Filipino representative; his proposals for the future of the islands; the issues discussed in the Cortes in relation to the Philippines; and the impact that all these matters had on the archipelago. 
he year 2012 marked the bicentennial of the Cortes de Cádiz and the Constitution of 1812.' This anniversary occasioned a large number of scientific studies aimed at analyzing a wide range of questions related to that historic moment. In these studies, the participation of the Americas was a topic of special attention. Although dealing with the same historic phenomenon, this article covers an aspect that has received little attention-the presence of the Philippines at the Cortes de Cádiz. ${ }^{2}$ This article revisits the actions of the Philippine delegate to that assembly, Ventura de los Reyes y de la Serena, and the issues discussed at Cádiz regarding the Spanish empire's easternmost archipelago. ${ }^{3}$ Reyes was the first Philippine representative who genuinely had the opportunity to defend the interests of the archipelago in a parliament that brought together representatives from all of the territories then comprising the Spanish empire. Within that collective political structure, he tried to improve the situation of the Philippines, calling for expanded rights and conditions that were more favorable to the islanders' interests, and specifically to the interests of the social and economic group to which he belonged, the criollos (creoles), in this case Philippine-born people of Spanish ancestry. His participation in the Cortes de Cádiz and in later political movements was vital in the forging of the emerging politics of the Philippines as a nation.

\section{The Road to Cádiz}

To understand the presence and actions of Ventura de los Reyes in Cádiz, we must look to Europe and go back several years to the Cortes held in Bayonne in 1808, without which it is difficult to understand subsequent events. The period between October 1807 (the Fontainebleau Pacts) and April 1808 (the Bayonne Conference) was a turbulent period during which the following contradictory events occurred: the agreements between Napoleon and Charles IV to take control of Portugal and its empire and thus halt the British; the entry of French troops into the Iberian Peninsula; the departure of the Spanish monarchs from the Court at Madrid, first to Aranjuez, en route to Seville, and if necessary, on to the Americas-as Godoy had advised them to do-to seek refuge from the advancing French troops; the coup by the Prince of Asturias against his father, proclaiming himself king upon learning of the flight and being supported by a popular revolt; the dynastic struggle between father and son; and, finally, the conference in Bayonne, which brought together Charles IV, Ferdinand VII, and Napoleon, culminating in the abdication of the king in favor of his son, who in turn abdicated to the French emperor. As a result, Napoleon obtained not only the Spanish crown, and with it the desired control over a significant part of the peninsula, but also gained control of Spain's prized empire in the Americas and Asia. ${ }^{4}$

The French leader wanted to keep the empire united and avoid the possible disintegration of territories. He knew that to keep the empire united, he would need the collaboration of creoles. Aware of the unease of elites in the Spanish colonies, he understood that to keep those sectors within a single political framework, he would have to grant some of the aspirations they had been calling for since the eighteenth century: equal rights for provinces in the Americas with those on the peninsula; increased participation in the empire's political life; and freedom of industry, trade, and farming. For this reason, when he convened the Cortes in Bayonne in June 1808, Napoleon granted representation to the American territories and agreed to consider them as provinces, not colonies. This was a key development for the future of Spain's overseas possessions, including the Philippines. As Manuel Chust (2010) has argued, following the assembly at Bayonne and during the period of the war from 1808 to 1814, any proposal to reorganize the state would perforce include granting representation to Americans and Asians via members of parliament who could thereby defend the interests of their territories in a common parliament. Even later, in the repeated back-andforth changes between absolutist and liberal regimes that took place over the course of the nineteenth century, representation would be a key point in the different policy versions each proposed. Thus, events in Bayonne had longterm consequences and a direct impact on the future of the Philippines.

However, events did not unfold as Napoleon had planned. Both the peninsula and the overseas territories would soon revolt against French control. When the Spanish people learned of the abdication of the Bourbon monarchy and the penetration of French troops into the peninsula, which they saw as an invasion, they rose up against the foreign troops and called for Ferdinand VII, at that time called "the desired one," to return to the throne. While the situation was playing out and in order to avoid a power vacuum on both sides of the Atlantic, and even in the Pacific, local and provincial councils (juntas) were created to assume executive, judicial, and military powers. These juntas, in turn, granted themselves sovereignty. In response to this hatching of scattered councils, on 25 September 1808 a Supreme 


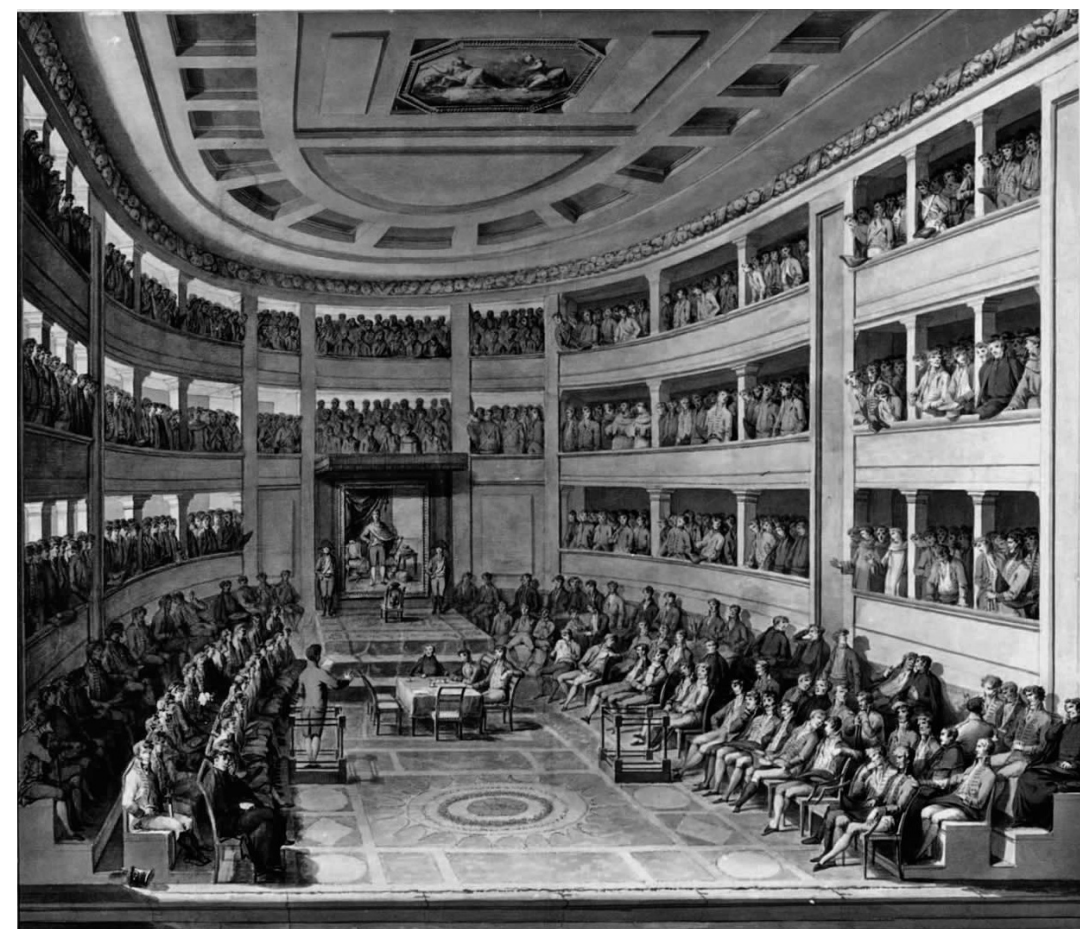

Juan Gálvez, Sesión de las Cortes de Cádiz, executed c. 1812. Source: Gálvez 1812

Central Governing Council of the Kingdom was created. It was to serve as the point of reference that would embody the government's legitimacy in the king's absence, thus offsetting the power that the other council authorities were assuming both on the peninsula and in the overseas territories. This governing council also proposed to reorganize the political landscape and coordinate all efforts to win the war against the French. ${ }^{5}$

To this end, the Central Governing Council deemed it necessary to convene a new Cortes. Following the path laid out in Bayonne, it decided that the overseas authorities that had remained loyal to the king would be represented. To facilitate this representation, in advance of convening the Cortes, the Central Governing Council approved a series of decrees that would have a direct impact on the status of the Americas and the Philippines. The royal order of 22 January 1809 declared that the Spanish dominions in the Indies were not colonies, but rather constituted an integral part of the Spanish realm. ${ }^{6}$ It also stipulated that each one of the viceroyalties (Río de la Plata, New Granada, New Spain, and Peru) and the captaincies-general (Chile, Venezuela, Cuba, Puerto Rico, Guatemala, and the Philippines) would send representatives to the Central Governing Council.

Months later, in February 1810, in the decree formally sanctioning the convention of the representatives to the Cortes for the purpose of approving a new constitution that would govern them, the Central Governing Council maintained the same spirit of openness, declaring the equality of metropolitan and overseas territories and inviting representatives from the American and Asian territories. ${ }^{7}$ In order to avoid delaying the assembly of the Cortes it was decided that residents of those territories who were already living on the peninsula would take the place of recently elected overseas representatives whose participation required long voyages. Thus the Cortes that went on to approve the Constitution of 1812 was convened with nearly 100 members, twenty-nine of whom were substitutes awaiting the arrival of the real representatives from their respective provinces. The first session of the Cortes was held on 24 September 1810, in the San Pedro y San Pablo Church on the island of León in the Bay of Cádiz, where the members had taken refuge to escape the battles against the French that were still being waged in other areas of the peninsula. There the delegates took the oath of office, promising to safeguard the interests of the Spanish realm. Over the course of 1811, the real representatives gradually arrived from their respective provinces, in time to participate in the constitutional debates and vote on the new constitution, which was approved on 19 March 1812 (see fig., p. 334).

\section{Creoles and the Philippine Representatives}

In the first few months of the Cortes de Cádiz, the Philippines was represented by two substitute members. One was Pedro Pérez de Tagle, brother of the Marqués de las Salinas. Pérez de Tagle was a career soldier from a distinguished creole family, an officer in the Royal Spanish Guard, who had business dealings with the Royal Philippine Company; he had virtually no role in the Cortes. The second was José Manuel Couto, who was born in New Spain (Mexico) and had connections to the Mexican interests surrounding the Nao de Acapulco or galleon trade. Couto's participation in the Cortes was brief because in January 1811 he was granted permission to return to Veracruz for health reasons (Díaz-Trechuelo 1999, 447; Llobet 2011, 139). 
Meanwhile, in the Philippines the election of the islands' representative was being organized. Notices that elections to the Cortes would be held were contained in the Royal Orders of 22 January and 9 October 1809, which first reached Manila in March 1810. Months later, in July 1810, the new governor of the Philippines, Manuel González de Aguilar, who had taken his post in March of that same year, acknowledged receipt of the announcements and proceeded to organize elections. ${ }^{8}$ A decree dated 14 February 1810 had stipulated that representation of the vice-royalties and the captainciesgeneral would be maintained and one member of parliament was allotted for each of the municipal councils (cabildos) located in provincial capitals (cabezas de partidos). Based on this regulation, only Manila was eligible to send a representative because its municipal council-in 1810 controlled by creoles-was the only one with this status then in existence in the Philippines. According to the same decree, the election of representatives should correspond to each provincial capital's city council, which would name three people, native to the province, "with integrity, talent, and instruction, and free of all censure." They had to be Spaniards born in the territories they would represent-although in the case of the Philippines, in clear deference to its close ties to New Spain, the decree specified that creoles born in the Americas were also eligible. ${ }^{9}$ Likewise, delegates could not hold any significant public post, such as that of governor, mayor, or member of the Royal Court of Justice, although they could form part of other lesser institutions, such as Manila's municipal council. They should not have any outstanding debts to the Royal Treasury. Of the three names, the one who was selected first in a random draw would be named as the representative to the Cortes. Following these instructions, on 6 November 1810 an electoral board made up of the governor-general, the archbishop of Manila, and three representatives from the Manila municipal council, chose Ventura de los Reyes as representative of the Philippine province.

Ventura de los Reyes, at 71 years of age, was a man advanced in years and of established prestige. There exists but scant information about him, but through an existing will we know he was born in 1739 into a wealthy family in Ilocos. ${ }^{10}$ His father was Santiago de los Reyes Cardona, a merchant who was born in Barcelona, and his mother was Vicenta Sánchez, a Filipina of mestizo parentage. He formed part of the Royal Artillery Corps before becoming a prosperous merchant in the business of indigo and other plant dyes (Yuste 2007, 254, 448). He broadened his horizons, exploring not only the traditional merchant route to Mexico but also trading with ports in southern China and India. He married three times, the last two to women from the Monterosso family, an important long-standing creole family involved in the galleon trade, with some of its members having formed part of Manila's municipal council. He also enjoyed good relations with the colonial administration and was a business partner of the interim governor, Mariano Fernández de Folgueras. ${ }^{11}$

According to the ethnic and territorial classification scheme, which distinguished between indios (natives), mestizos, creoles, and foreigners, Reyes belonged to the group of creoles. This category, which referred to Spaniards born in the Philippines, was more complicated and diffused in this archipelago than in other places. Members of this group were variously called filipinos españoles (Spanish Filipinos), insulares (Philippine islanders), or hijos del país (sons of the country). By the nineteenth century, the use of the word creole was unusual. In theory, a creole was a Filipino of Spanish parentage, and therefore white. However, racial purity in the Philippines was not consistently maintained. In creole families there was often interbreeding with other races, with the mother, or to a lesser extent the father, being a Philippine native, Spanish mestizo, Chinese mestizo, or Chinese. This phenomenon became increasingly common in succeeding generations. In this sense, creole group membership was marked by Spanish ancestry, an elevated social and economic status, and a certain proximity to peninsular Spaniards and to the colonial government, although the latter circumstance tended to fade in importance with the passage of time.

In any case, Philippine creoles were part of the country's elite. They were settled in the Philippines in a stable way, without any intention of returning to the peninsula, even while they maintained close links with it. They had strong economic interests in the archipelago and were involved in institutions of development and progress. Over time they became gradually more identified with the native population of indios and mestizos than with the Spanish population. As the nineteenth century wore on, although they worked in the colonial administration, increasingly they supported full rights for the native population in general, the introduction of a reformist policy, and finally Filipino self-government.

The ethnic background of the creole elite in the Philippines was unusually varied. Given that its Spanish heritage often included significant racial mixing, this group was, as a consequence, sometimes highly 
internationalized. Its members maintained close international ties bevond the archipelago. Similarly, it was common for creoles to treat their political identity with a certain ambiguity, sometimes accentuating their Spanishness, at others their Filipinoness. At times they even asserted a dual nationality. In the early nineteenth century, when most political identities were still poorly defined, creoles would claim not only to be of peninsular origin, but also of Mexican or Latin American descent. In the period following the independence of the American republics this flexibility largely disappeared.

Michael Cullinane (2003, 360 n. 32) has pointed out that

\section{Although the term "creole" implied a person of pure Spanish ethnicity born in the colonies, in the Philippines the term was applied more loosely and appears to have frequently been used for mestizos. Since racial classification was usually determined by the race of the father, many of those included as creoles ... were more precisely Spanish mestizos, in that their mothers were often mestizo, rather than creole.}

In the Philippines things were neither so clear nor so easy. Wealth, occupation, education, and integration within the Filipino society, and, at the same time, within the colonial administration, could change the adscription (ibid., 8-48).

Speaking of Trinidad H. Pardo de Tavera, Resil Mojares $(2006,202)$ has made an interesting remark concerning creoles:

In race-conscious Manila, he was not quite a Spaniard either. Neither limpios de sangre ("of unblemished blood"), nor Iberia-born (peninsular), he was a Spaniard born in the colony, a criollo, hijo del país, insular or español filipino. While mestizos and creoles were not legally discriminated against in colonial Philippines, they did not quite have the political ascendency and social cachet of peninsulares. This became an important distinction particularly after 1872 when matters of birth and race acquired distinct political overtones and many creoles became-in the eyes of the authorities and their ownFilipinos.

Mojares (ibid.) has also explained that
In the early nineteenth century, Filipino meant a Spaniard born in the Philippines. By the 1860s, however, the word was increasingly used by natives (indios), Chinese and Spanish mestizos, and creoles to identify themselves as members of an emerging, multiracial community politically set apart from Spanish peninsulares. The events of 1872 and their aftermath poisoned the atmosphere with suspicion, racism and blatant acts of vindictiveness that polarized sectors in colonial society and sharpened the divide between Filipinos and Spaniards. ${ }^{12}$

The creoles were few in number, never more than 3 percent of the population, but they had a strong influence on Philippine society because of their oversized role in the colonial economy and politics. Many creoles who were roughly contemporaries of Reyes played important roles in the colonial Philippines. Among those who might be listed exemplars of this class were Luis Rodríguez Varela (1765-1824), poet and alderman of Manila's cabildo (municipal council); José de Avilés, lieutenant colonel in the royal army; Juan Verzosa, colonel of the militia and notary (escribano mayor) of Manila's cabildo; Domingo Roxas (1782-1843), one of the most prosperous businessmen of the Philippines in the first decades of the nineteenth century; and the lawyer José María Jugo (1780-1855) (ibid., 202, 411-14).

The creoles became so important during the years 1809 through 1814 because they controlled the institutions that would elect the representatives to the Cortes, as was the case of the municipal council of Manila. In this sense Ruth de Llobet $(2011,123)$ has noted that as a consequence of their leading role in

the election of a deputy to represent the archipelago in the Cortes, creoles gained agency in the archipelago .... They brought their commercial and political interests to the table at the Cortes. While their economic agenda was liberal in its conception, their political agenda was centered on maintaining the status quo because of the fear of the native element in an electoral context and the capacity of indios to overwhelm creoles and Spaniards by their numbers.

From these comments on creoles, let us now return to our main subject. After being named representative of the Philippines, Reyes arrived 
in Cádiz filled with aspirations and a long list of claims in favor of his compatriots, especially the creole circles from which he came. He was, furthermore, convinced of the truth of that proclamation, which would soon be reconfirmed in the Constitution of 1812, that this was a meeting of Spaniards from both hemispheres, with equal rights and powers, willing to work shoulder to shoulder for an inclusive and plural polity, where all could dream of a more just future. With this outlook, he joined the Cortes on 6 December $1811,{ }^{13}$ still in time to debate the creation of a new political and economic order and sign the new constitution. In the chamber he took part in the debates regarding the Philippines, especially in regard to the political representation that the archipelago should be given, the reforms necessary for its progress, and the future of the Manila Galleon and other trade issues in the islands.

In February 1812 Reyes submitted a complete reform plan for the Philippines, which contained twelve proposals. ${ }^{14}$ For some propositions, more information was requested; other proposals that involved questions that encroached on the powers of the Regency Council were sent to it for decision. Still others were deemed to have been addressed in the Cortes and awaiting decisions, such as the deregulation of tobacco requested in the seventh proposition. In some specific cases - such as the fourth proposition regarding the elimination of the galleon trade, and its replacement by a commercial substitute in the Philippines - the proposals were discussed at length in the Cortes.

\section{Trade After the Galleons and Impact on the Empire}

The Manila Galleon had been a key trade mechanism for the Philippines for several centuries. It had made Manila the axis of a transpacific trade route drawn between the Americas and Asia, because it was in Manila where American silver was exchanged for Asian products brought in on board Chinese junks. These products were later sent to Acapulco, where they were redistributed to the rest of the world. Such a trade route gave the Philippines a purpose within the Spanish empire and made it possible to maintain a colonial government in the islands, dependent as it was on the vice-royalty of New Spain. This trade also fostered a wealth of cultural, scientific, artistic, and human exchanges that enriched the various societies involved. However, with the exception of the elite who participated directly in that trade and of those sectors necessary for the galleon system to function- shipyards; suppliers of sails, rope, food, and others-the Manila Galleon did not generate wealth among the islands' populations and it did not drive development within the Philippine archipelago. Rather, it restricted the growth of the islands' production and industries, which had minimal involvement in the galleon trade. Consequently, after the route's decline in the eighteenth century, criticisms strengthened against this trade monopoly, which stopped operation in the early decades of the nineteenth century, with the final voyage of the galleon sailing in 1815 (Schurz 1939; TePaske 1983; Yuste 1984, 2007; Martínez Shaw and Alfonso 2000; Legarda 1999; Alonso 2009).

In this context, on 7 July 1810, then governor-general of the Philippines González Aguilar presented a proposal requesting the elimination of the galleon that connected Manila and Acapulco, alleging that since the Nao was oriented toward other Asian products, it removed incentives for Philippine agricultural and industrial production. Furthermore, he argued, the continuous entry of products from other parts of Asia hindered the economic development of the archipelago. According to González Aguilar, land in the Philippines was abundant and fertile, and its inhabitants agile and hard-working; however, their work was obstructed by the exclusive privilege enjoyed by the Royal Philippine Company, which impeded local industry, oppressed and disabled harvest workers, and prevented their growth and labor. That part of Asia, he argued, being an integral part of las Españas, was a hidden treasure and a rich possession that needed to develop its own resources to ensure a promising future. Therefore, in order to remedy the harm that was being caused by the galleon trade, he proposed the suspension of the established route of the galleons and, in order to avoid harming the islands' trade during the change, that it be allowed to operate freely and carry both local and other Asian products on its own ships to any of the destinations and ports in the Americas, without exceeding revenues of more than Pl million per year (España Cortes Generales 1813b, 4877). The Cortes organized at Cádiz saw these arguments in a positive light, and on 8 October 1811 it approved the elimination of the Nao de Acapulco, although the measure was not made public pending a general decree on trade in the empire as a whole. ${ }^{15}$

When Ventura de los Reyes joined the Cortes, he took up the subject again, reiterating the request to eliminate the galleon trade and proposing that from then on Philippine merchants, and not only peninsular Spaniards 
residing in Manila, be the ones to continue the transpacific trade using private vessels. To this end, he requested that those private vessels be allowed to go to the ports of Acapulco, San Blas, or any other port in New Spain. He also advocated that the same permission granted to the galleons to transport cargo valued at P500,000 on the voyage from Manila to the Americas and P1 million on the return voyage to the Philippines be maintained. Likewise, he called for a 50 percent reduction in existing customs tariffs and an end to the organization of the trade through the system of boletas for acquiring space on the ships, a system responsible for restricting the participation of Philippine merchants in those exchanges. ${ }^{16}$

Reyes was a staunch defender of free trade. As such, he did not support the galleon's privileges because, from an economic perspective, he felt the people of the Philippines had gained little benefit from it. However, he was not opposed to continuing trade along the route that connected Asia and the Americas via Manila. Rather, he was opposed to the monopolies that prevented the increased incorporation of Philippine merchants and the islands' products into that dynamic. He also understood that the elimination of that trade route would harm his province and the trade potential of the islands. For this reason he requested that Philippine merchants be allowed to continue the Nao's trade in conditions more favorable to them. This matter was discussed for months in the Cortes de Cádiz.

Reyes's proposal was sent to the Regency Council and the Special Trade Commission, which then drafted a decree to eliminate the Nao de Acapulco and supplement the Philippine government's lost revenues generated by this trade. This decree was read in the Cortes on 25 March 1813. The dictate was very generous. First, it agreed to the immediate publication of the formal elimination of the galleon trade the approval of which had not been made public previously. Second, it agreed that the Nao should be replaced by private Philippine merchant vessels, and specified that both the quantity and quality of the goods that those ships could transport, as well as the ports with which they could trade, were questions that would be determined in accordance with a national free-trade policy, which would benefit Spaniards in both hemispheres. It also stipulated that the substitution of the Nao de Acapulco by Philippine merchant ships should be carried out immediately, without waiting for the resolution of a general trade policy for the greater Spanish empire, so as to enable the archipelago to develop its economy. Third and last, it specified that the ships that replaced the galleons could transport goods valued at $\mathrm{Pl}$ million on the outbound voyage and double this amount on the return, which was higher than the amount requested by Reyes. Likewise, Reyes had asked, rather generically and ambiguously, that Philippine merchants be allowed to continue that trade, without specifying the type of products that would be exchanged. Nevertheless, the Special Trade Commission mentioned both the "products and goods of the islands," which would be "perpetually free for trade with all of the other provinces of the empire." Its report also stipulated that, until a national trade law was passed, "goods from China and other countries on the Asian continent" should be included within the aforementioned quantity of $\mathrm{Pl}$ million. This latter resolution opened a new area of discussion in the parliamentary debate. In any case, it was a report that was entirely favorable to Philippine interests (España Cortes Generales 1813b, 4877). ${ }^{17}$

The Trade Commission's decision was hotly debated in the Cortes, with discussions extending to the sessions on 25 and 29 March 1813, and which remained open for several months until the question was finally resolved in September 1813. Several members from the Iberian Peninsula participated in the sessions; among them were two Catalonian members, Juan del Valle and Jaime Creus, and a representative from Granada, Antonio Porcel, who supported a policy that would protect peninsular industries. On the opposing side were several members from the overseas territories: José Mejía Lequerica, born in Quito; Florencio del Castillo, member from Costa Rica; and Antonio Larrazábal, representative from Guatemala, all of whom were firm defenders of equality between the peninsula and the overseas territories, and a policy of free trade between different parts of the empire.

The discussions among these members focused on several points. First, they debated the utility of allowing Philippine merchants to continue the trade that had previously been carried by the galleons, once its monopolistic nature had been eliminated, in order to promote the development of the archipelago, its production, industry, and trade. There was general agreement in regard to this point (España Cortes Generales 1813b, 4882, statement of Lequerica).

Second, there was discussion as to whether this question affected just the Philippines or the entire Spanish empire, and therefore whether it was necessary to think in specific or general terms. What was actually being debated was whether a specific measure that would allow free trade in the Pacific supportive of the development of the Philippines should be passed, or 
whether opportunity for all should be safeguarded such that all regulations adopted would extend to the entire empire and protect its unity despite the distances and differences among the various territories. Would the prosperity of the Philippines benefit the entire Spanish nation, or, if transpacific trade was opened for the Philippines, should that same free trade be extended to all Spaniards, regardless of whether they were European, American, or Asian? Was it beneficial to adopt a specific measure that gave more trade possibilities to Philippine merchants, or would it be better to design a system of trade that was fair and beneficial for all, without favoring any one sector, regardless of whether it hailed from Manila or Cádiz? Behind this debate was an undercurrent in defense of the various trade interests in the overseas territories and in the peninsula (España Cortes Generales 1813c, 4920, statement of Creus; 1813b, 4879, statement of Valle; 1813c, 4914-16, statement of Larrázabal).

This discussion led to a third point, namely free trade. At issue were: first, whether or not to establish free trade for all, and second, whether free trade should extend to the limits of the empire or to trade with other countries. In this regard, the overseas representatives advocated the adoption of free trade for the whole empire. They spoke out against the privileged trade conditions enjoyed by peninsular Spaniards and said that, if the overseas provinces were not allowed to trade with each other, all of those goods that the peninsula could not provide would be bought from foreigners, who in the long run benefited from those trade conditions and were truly growing wealthy, thanks to the Spanish Indies (España Cortes Generales 1813c, 4914, statement of Castillo; 1813c, 4915-16, statement of Larrázabal).

Fourth, they debated the question as to whether Philippine ships should include other Asian products in their cargo or whether national products (products produced in the Spanish territories) should be favored. In that controversy, both the Catalonian Valle as well as Granada's Porcel defended the position that the entry of Asian products other than those from the Philippines into Spanish territory via Philippine ships was harmful for all parties involved. For the Philippines, it would not encourage the production and exports of the islands, which was one of the reasons for the elimination of the galleon trade. For the American provinces, it would ruin their industries; for the peninsula, the entry of textiles from other countries would harm the domestic industry, which thus needed to be protected. For these reasons, they defended the position that the Philippines should trade goods produced in the archipelago but not other Asian products, which would only prolong the status of the Philippines as an intermediary economy. They said that what needed to be emphasized was free trade for Philippine products in ports of the peninsula and Spain's overseas provinces; in other words, free trade for Spaniards with Spaniards. What was important was to "protect and promote domestic industry, favoring local commodities and products against foreign products." Reyes responded to those speeches by saying that they had misunderstood the Philippine governor's request because, given the state of the country's agriculture and industry and the similarity of the products from the archipelago and New Spain, he would never have requested that Philippine merchants be allowed to trade up to a value of $\mathrm{Pl}$ million had he not counted on carrying Chinese and other Asian products (España Cortes Generales 1813b, 4881, statement of Reyes).

After all of these points had been presented and debated over the course of several sessions, finally on 10 September 1813 a conclusion was reached on the matter. On the 14th of that same month, a decree was approved that directed the elimination of the Manila Galleon, promoting in its place the continuation of trade between the Philippines and New Spain on Philippine ships that could carry other Asian products but only in limited quantities. ${ }^{18}$ In short, after months of discussion, Reyes achieved all of the objectives that had been proposed in regard to trade in the Philippines after the end of the galleons.

Sometime later, in the session held on 8 October 1813, Reyes ratified his position in favor of free trade and presented a plan to develop agriculture and trade in the Philippines. He proposed that the archipelago's products be sold freely in all ports of the empire, without the need to pay customs tariffs. He also requested that Philippine merchants be the suppliers to Spanish missions and forts established in northwest California. There was not enough time in the Cortes to discuss these measures, but they were approved later, in 1815, when a new policy on free trade for the empire was approved.

\section{Equality for the Philippines?}

\section{Travel, Distances, Elections, and Citizenship}

One of the great achievements of the Cortes at Cádiz was the proclamation of the equality of both the territories and the inhabitants of the empire, which satisfied one of the aspirations long demanded by those born overseas. On 
15 October 1810 this desire for equality was ratified in Cádiz with a noble declaration, which was later confirmed in the constitution:

That the Spanish dominions in both hemispheres form a single, unified monarchy, a single, unified nation, and a single family, and that, for the same reason, that those born in those domains, both European or overseas, are equals in terms of rights with those of this peninsula, with the Cortes responsible for handling, opportunely and with particular interest, all those questions that could contribute to the happiness of the inhabitants overseas. ${ }^{19}$

Nevertheless, this theoretical equality was overpowered by day-to-day practices, which held out against a theoretical leveling that was difficult to achieve. First, the affirmation that all of the territories belonged to a single political space meant that they were all subject to the same laws and must accept the decisions made by the institutions that represented the country, with no exceptions to account for specific circumstances. Or so, said the laws. But the policy was difficult to put into practice. In the case of the Philippines, this question sparked a drawn-out debate in the Cortes, where discussion centered around whether it was preferable to impose the same laws appealing to equality, even to the detriment of a territory; whether it was better to respect its uniqueness, accepting behaviors different from the rest of the empire; or whether this could lead to abuses by the authorities, which, alleging this difference, could set different guidelines for their actions.

Second, the presence in the Cortes of peninsular and overseas Spaniards was not numerically equal. Although the inclusion of representatives of the overseas provinces in the Cortes was a most important development, also important was the fact that they were never proportionate to the number of inhabitants they represented. In both the Central Governing Council as well as the Regency of the Kingdom, the representation of the overseas provinces was in the minority in relation to peninsular Spaniards. Likewise, in the Cortes that was to draft a new constitution, close to 200 members had been called to represent the 11 million inhabitants of the peninsula-one for every 50,000 - while fewer than thirty members represented the 16 million inhabitants of the overseas provinces, without taking into consideration the actual number of inhabitants of each territory. ${ }^{20}$ Even in the first regular session of the Cortes following the approval of the constitution, elected in accordance with the decree dated 23 May 1812, which began to set the number of members based on population, it was stipulated that the representatives of overseas provinces would be approximately 100, as compared to the 150 from the peninsula. Once again, the figure of $100 \mathrm{did}$ not represent the true numerical reality of the population in the different territories. This figure was settled upon in order to safeguard the dominance of peninsular members by discriminating against many overseas inhabitants, establishing a series of iron-fisted rules that stipulated who could be elected and who the electors were, thereby drastically reducing the electoral base. There was therefore a clear contradiction between the formal equality and the practical inequality of representation (Fradera 2005, 67-68).

And, third, by introducing racial criteria to indicate who could be a citizen and who could not, a significant portion of the overseas population was shut out. In the Philippines, the category of castas pardas, or classes with African blood, was less clear-cut because, although there were no descendants of Africans, there was a population of color (the Negritos or Aeta peoples). Consequently, the matter was left to whoever was called upon to define who would and would not form part of the citizenry. This resulted in the use of all types of trickery that were devised for those occasions when it came time to grant true representation to all of the inhabitants (ibid., 77-83; 10-11; Fadera 2008, 9-30; Fenner 1985, 114-79; Aguilar 1998, 156-88; Cullinane 2003, 8-48; Cullinane 1981, 251-96; Cushner 1971, 209-12). In this context of negotiating true political representation for the various parts of the empire, in the course of his participation in the Cortes, Reyes, on at least two occasions, ran into the problem that the desired equality between territories and inhabitants could not always be put into practice in the Philippines due to the different circumstances obtaining there and elsewhere.

On the first occasion, Reyes highlighted the difficulties that distance and climate posed for the Philippines when it was time to incorporate it into a collective political existence with the rest of the empire: "the distance of the Philippines is undoubtedly incomparable with the distance of any of the American possessions." And what was worse, in this regard not everything depended on the will of the people. Since steamships did not yet exist and the Suez Canal had not been opened, communications between the Philippines and the peninsula had to be carried by sail, either via the Americas and the Pacific, or by going around the Cape of 
Good Hope and crossing the Indian Ocean. In any case, it was rare for the trip to take less than three months of sailing, plus the time needed to undertake the voyage in the appropriate season. One could not simply depart. Travel by sail was entirely dependent upon favorable conditions including weather, the strength and direction of the wind, ocean currents, the monsoon season, and the effects of typhoons. Based on these variables, there were times when travel was possible and other times when it was impossible. This meant that the time to wait for a suitable time to travel, plus the travel time itself, would often be a full year or more.

As Reyes pointed out, this prevented the Philippines from reacting quickly to an announcement to convene the Cortes, or to arrive on time at a political event, unless it was planned months ahead of time. It was necessary to take into account not only the long period that would be required for a member to travel from the archipelago to the peninsula, but also the time that it would first take the news of that announcement or meeting to reach the Philippines, not to mention the time needed to organize elections in the islands. Reyes illustrated this problem by indicating that, if an announcement that the Cortes would be held were made at that time (May 1812), in the best scenario the elected member would not reach the peninsula until two years later:

At present, any news that is to be sent there cannot be sent because the season for the departure of the ships, which are the months of February and March, has passed. If the Nao in Acapulco has not departed, it may do so in the month of November and arrive in the Philippines at the beginning of January in the year '13. The difficulties that will be encountered there in holding the elections, due to the passing monsoons to which the islands of Visasmo are subject, will take up all of 1813; but if we assume that by the start of ' 14 , the members will be prepared to travel, they must depart sometime around the month of January and will arrive here in the month of May, if they sail straight here. If they are forced to come by way of the Americas, they will not arrive until November or December of '14, by which time the Cortes for that year will have concluded its sessions. And so it is impossible for the Philippines to have representatives here for ' 13 , and will only have them here, at the earliest, by the end of '14. (España Cortes Generales 1812b, 3154) ${ }^{21}$
In these conditions, Reyes said that the best possible solution to allow the Philippines to keep in step with the political rhythm of the other territories would be to prolong the system of substitute members while waiting for the elected members to arrive. It meant that, at that time, Philippine representation in the Cortes would remain under the control of Reyes, with the powers that this gave him to continue to defend creole interests. Also, this proposal by Reyes simply entrenched existing difficulties of synchronizing the rhythms of the different territories and reaffirmed the idea that it would be difficult to assimilate the Philippines into the rest of the empire. This solidified the idea of difference, which was a dangerous argument if equality was the goal.

This circumstance would become even more pronounced on the second occasion, when Reyes pointed out the impossibility of harmonizing the Philippines with the rest of the empire. In accordance with the decree dated 23 May 1812, each territory would elect its representatives based on the number of its inhabitants. This meant that, based on its population, more than twenty-five representatives would correspond to the Philippines. However, Reyes declared in the Cortes that the Philippines could not fulfill that condition "due to the enormous distances, the educational level of a large number of the inhabitants, the variety of languages and dialects, and in short, the virtual impossibility that the islands would be able to cover the significant expense that would have to be generated to support the number of representatives that correspond based on its population" (España Cortes Generales 1812c, 3191). For this reason, he proposed that the Philippines send just two members:

I must clarify to Your Majesty that the Philippine Islands have $1,800,000$ inhabitants, with more than 25 representatives corresponding to them. Likewise, I must also say that these islands are experiencing an extreme lack of funds; and that in regard to whether or not they would be represented by one or two members, I proposed that they be released from the obligation of sending the entire number that corresponded to them, also taking into consideration the extremely long voyage of more than 6,000 leagues that the representatives of the islands must make, regardless of where they come from. (ibid.) ${ }^{22}$ 
At this point, Reyes proposed that due to the difficulties of electing the representatives of the Philippines, for the time being they should send two representatives elected in Manila; the election of other representatives from the provinces would be proposed later. This proposal avoided all of the aforementioned problems and prevented the Philippine indios, who were more numerous, from overtaking the peninsular Spaniards and creoles in holding the reins of power. With this proposal, was Reyes defending the position that the political power of the Philippine members in the Cortes remain in the hands of creoles, sidestepping the possibility of the entry of broader sectors, especially the inclusion of representatives of Philippine indios and Chinese mestizos in the Cortes? Only as a defense of the political privileges of an elite against the intrusion of a new majority from other social circles, rather than on account of the economic motives that Reyes alleged, is it possible to understand the disservice done to the Philippines in Reyes's call to reduce the number of representatives in the Cortes that legitimately corresponded to the archipelago according to the number of its inhabitants. He seemed to defend keeping the election of Philippine representatives in the hands of the Manila municipal council, which was so closely tied to creole interests, rather than extending it to the broader population of the archipelago, thus restricting the participation of the native population in the Cortes. ${ }^{23}$

The Constitution Committee of the Cortes studied Reyes's request and concluded that it could not be satisfied because not even the smallest change could be made in the system that the constitution had established for holding elections. However, it did acknowledge that the observations by Reyes did show "that many of the native-born people, who cannot be correctly deemed as citizens, currently enjoy the rights as such," and that therefore they could not be elected or be electors. It was deemed necessary to have the intervention of a preparatory electoral council "that will know how to overcome the surmountable obstacles in the most convenient manner and manage all of the temperaments" so that the general stipulations could be made applicable to local circumstances without breaking the law. The committee also understood that, "if the level of wealth of the native citizens does not permit them to maintain all of the members that may correspond to the number of their population, it is up to the province in question to use the right granted by the Constitution to a greater or lesser extent." It stipulated that the Philippines could freely send the representatives as permitted by its population and circumstances, without implying a loss of rights or the requirement to reduce the number of members that corresponded numerically to them. ${ }^{24}$

The request by Reyes alarmed the American members, who feared that the peninsular authorities would be able to cut back their rights using that same line of reasoning. Ramón Olaguer Feliú, a substitute member for the vice-royalty of Peru, warned that if they were discussing whether or not the Philippines could send just two representatives even though more corresponded to it, due to the lack of education of its inhabitants and limited funds, those circumstances would occur also in American territories. He feared that some viceroys, in applying this strategy, would reduce the representation of that part of the Spanish empire. Consequently, he proposed that, if resources were required, a common fund be created to finance the participation of representatives from all of the territories (España Cortes Generales 1812c, 3191). Along this same line, Francisco López Lisperguer, a substitute representative from the vice-royalty of Buenos Aires, said that the letter of the constitution should not be altered to avoid giving the viceroys and overseas captains-general margin to abuse it and thus reduce the representation of the Americas (ibid., 3192). In the same vein, José Mejía Lequerica, member from the vice-royalty of Santa Fe, insisted that it was preferable to respect the rights of each territory as they were established; later, based on their circumstances, the territories could do what they deemed most appropriate on each occasion, without suffering a reduction in their rights or the acceptance of the arbitrary decisions of individual viceroys or the loss of representation (ibid.).

Agustín de Argüelles, a member of the committee that had evaluated this question, closed the debate by saying that the presence of Reyes in Cádiz had cost 10,000 duros, which meant that the arrival of twenty representatives from the Philippines would cost 200,000 duros, which was probably more than what the archipelago could afford to pay. The idea was therefore not to force the Philippines into an effort that it could not handle. For this reason, the fairest position was considered to be, in addition to what Reyes had requested, to not reduce the representation that corresponded to the Philippines, but rather maintain it and accept that they would send as many representatives as they could afford. This policy was what was followed (ibid., 3191-92).

It was possibly the fairest, and perhaps the only possible, option given the situation in the Philippines at that time. However, a negative precedent was 
being established. Because of the distance between the Philippines and the peninsula, the level of education of its inhabitants, and the level of wealth of the other islands, differences were being established with other territories in the empire. Those same arguments would be used in 1837 to justify the special legislation that sought to distinguish the overseas archipelagos from the peninsula and return them to the status of colonies.

\section{The Impact of Events in Cádiz}

In any case, between 1811 and 1814, there was one Philippine member fully integrated into the Cortes, defending the political, social, and economic hopes of the Philippine population within a common legal framework that joined representatives from all parts of a global empire, which at that time still remained politically intact.

There was at least one Philippine representative who voted for a constitution that expressly declared that "the nation of Spain" consisted of all Spaniards in both hemispheres. This constitution spoke of las Españas, underscoring the diversity of territories that comprised the monarchy, with provinces that shared an administrative uniformity and possessed equal rights and representation in the parliament. This declaration opened the possibility to rethink the Philippines within the empire, in the context of a framework that was significantly more favorable to the archipelago and its inhabitants.

In fact, the constitutional process experienced in Cádiz, and the later ratification of the Constitution of 1812, meant for the Philippines and other parts of the empire the birth of the public sphere in the Hispanic world. It ushered in the transformation of the overseas territories into provinces with parliamentary representation, and the theoretical right to participate in political life with civil and political equality of Spaniards in both hemispheres. All of these ideals were greatly desired and the urge to truly put them into practice would continue to drive the political demands of the Philippines throughout the nineteenth century.

Nevertheless, a new problem emerged due to the fact that, while the Cortes de Cádiz offered the Philippines the opportunity to have representation in a common parliament for all of the territories of the empire, this significant step forward favored the creole sectors around Manila's municipal council, the only one that could elect representatives to the constituent Cortes. It had a much more limited impact on the rest of the population of the archipelago.
During those years, the creoles used their presence in the Cortes to strengthen their political power within the archipelago and in their relations with the peninsular authorities. In order to maintain their power beyond the first elections to the Cortes, they emphasized Manila's superiority relative to the rest of the archipelago, in an effort to prevent the recognition of other municipal councils in the islands that would have brought other ethnic groups into the circle of representatives. This meant that the Philippine natives and mestizos had to be content with the power opened to them at the level of the barangay and institutions such as the ethnic-based gremios or corporate councils.

Following the declaration of the equality of Spaniards in both hemispheres, the recognition of the right to political representation in the parliament, the elections held in Manila, the incorporation into a general Cortes, and participation in overseas political offices, the Philippine creoles developed an awareness of their own identity that was distinct from that of peninsular Spaniards. From the Philippines they began to demand greater participation in the political life and decisions of the empire. They were placed on a path of increasing political involvement, which continued to develop during the decades that followed.

However, this path was not followed by the creoles alone. On the one hand, the feeling of being creole, insofar as the term referred to Spaniards born in the Philippines, disappeared progressively in the islands. After the 1820s, the descendents of the Spaniards began to identify themselves increasingly as Filipinos (Mojares 2006, 202). And, on the other hand, other ethnic groups of the islands were fully integrated into the movements that were calling for their own space of political power and demanding rights from the colonial regime.

The Constitution of 1812 also underscored the conviction that, from that time forward, sovereignty resided in the nation and marked a change from subjects to citizens - although who in the Philippines would be considered a citizen still awaited debate. Implementing all of those changes and adapting the new direction laid out by the constitution to the reality of the islands would be a drawn-out, complicated, and conflictive process, filled with steps forward and backward, with negotiations and confrontations, generated around the vital question of the balance of power between peninsular Spaniards, creoles, Filipinos, and Chinese. ${ }^{25}$

The constitution reached the Philippines at the beginning of 1813 , although news of it had circulated via British gazettes brought by English 
ships. It was formally proclaimed in Manila on 17 April 1813, and sworn to in the Manila Cathedral on the following day. The governor-general, González de Aguilar, ordered that it be published in all of the provinces and explained to all inhabitants to inform them of the new political order. After a long period of uncertainty and insecurity - in which there was a decided lack of accurate news, uneasiness in regard to the echoes of a war the progress of which was not known for certain, and a proliferation of rumors of successive political changes in the peninsula - the Constitution of 1812 was warmly welcomed in the islands. This reception was not only on account of its content, which in certain circles was received gleefully and in others with obvious fear, but also and above all for the return to a clear and orderly political legitimacy.

However, the constitution did not have a uniform or homogeneous effect throughout the archipelago. What took place in each territory was different, due to the coexistence in the Philippines of highly diverse societies that responded differently. In Manila and its surrounding areas the impact of the new Magna Carta was eminently political, as in these areas what was sought above all was equality and full rights for the Philippines - or at least certain circles of people in the Philippines - in relation to peninsular Spaniards, and also favorable economic conditions determined by increased freedom of trade. The fiercest struggles to keep power in the hands of peninsular Spaniards, creoles, and other groups were focused in these areas (Llobet 2011, 2009; Mojares 2006, 411-18).

In contrast, in the inland towns and in the rest of the archipelago, one of the most important effects of the Constitution of 1812 was the abolition of the native tribute and the obligation to endure polos y servicios (the system of forced labor), which was a major liberation for a significant part of the population. In many places, peasants considered these economic mechanisms to have reached their end and refused to continue respecting them, rising up against the gobernadorcillos (municipal mayors) who were responsible for collecting tribute and organizing community services. ${ }^{26}$

Once the Constitution of 1812 reached the Philippines, new elections to the Cortes began to be organized. These elections chose representatives in all of the city councils with more than a thousand inhabitants, a process which opened the door to the election of Philippine natives, mestizos, and Chinese as representatives. Although in theory the new Governor-General Gardoqui began to work in this direction, the instructions established in the constitution were soon curtailed. No new municipal council was actually recognized in the provinces, even when they had the required number of inhabitants. The colonial authorities were still overly fearful of the consequences of implementing the constitution in a territory populated mainly by natives. After a time, the Junta Preparatoria (Preparatory Council), learning of the difficulties of implementing the election requirements in many parts of the archipelago, decided that the elections in the Philippines would be restricted to the area of Manila and its environs, and that elections elsewhere in the archipelago would be postponed (Llobet 2011, 175-76, 185). This new denial of political rights, even though it benefited the creoles, caused significant discontent among the rest of the population of the islands.

In any case, when Ferdinand VII took the throne and decided to return to an absolutist government, the constitution was repealed and, in theory, things went back to the way they had been before. This meant a general loss of political power for creoles, Philippine natives, and Chinese mestizos, and also the reinstitution of the tribute and the polos y servicios. In reality, however, nothing would ever be the same. Many among the more important Filipinos, both creoles and natives, had felt themselves as equals of Spaniards and with full political and civil rights, and they would resist losing that status. Not only creoles, but also members of indigenous principalías and prominent members of the Chinese and other mestizo groups had already begun processes of political renewal that would prove difficult to stop.

Thus, in the first decades of the nineteenth century, following the participation of Reyes in the Cortes de Cádiz, in the Philippines a process was commenced that would take shape over the course of the entire century and prove vitally important in the forging of an independent Philippine nation. As Nick Joaquin (2005) has argued, these initial political struggles undertaken at the beginning of the nineteenth century can be considered important antecedents to the Propaganda Movement founded by José Rizal and those other notable ilustrados who inspired the Revolution of 1896.

\section{Notes}

This article was prepared as part of the research project "Imperios, Naciones y Ciudadanos en Asia y el Pacífico" (I) and (II), ref. HAR2009-14099-C02-02 and HAR2012-39352-C02-02, Spanish National Research Plan. A different Spanish version of this work will be published in the journal Historia y Política. I would like to thank Courtney Johnson and Bill Reilly for their translation of the Spanish manuscript to this English version. 
1 The Cortes de Cádiz was the first parliament of Spain with sovereign power. The sessions of the national legislative body, or parliament (traditionally known in Spain as the Cortes) met in Cádiz because of the French occupation of Spain during the Napoleonic Wars. The opening session was held on 24 Sept. 1810. The Cortes de Cádiz met as one body, and its members represented the entire Spanish world. In the history of Spain this body is seen as a major step toward liberalism and democracy. In March 1812 this parliamentary body approved the liberal Constitution of Cádiz.

2 An international conference on this question was recently held in the Philippines, the results of which are expected to be published soon: "From Cádiz to Malolos. Philippines and the Spanish Constitution of 1812," University of the Philippines, Diliman, 18 June 2012. This topic has also been covered by Celdrán 1994; Díaz-Trechuelo 1999, 2001; Llobet 2011; Castellanos 2012.

3 This archipelago is considered with the exception of the islands in Spanish Micronesia, which had strong ties to the Philippines.

4 In recent years, Spain's historiography that covers this period, the Cortes de Cádiz, and the enacting of the Constitution of 1812 has been quite extensive. Among other very notable works, the following have already become classics, along with other more recent work: Artola 2003; Portillo 2006; Aymes 2008; Chust 2010; Piqueras 2010; Lorente and Portillo 2011; Chust and Frasquet 2012; Fernández Sebastián 2012; Malamud 2012.

5 In January 1810, this Council would be replaced by a Regencia del Reino, or Regency of the Kingdom, which was responsible for guiding political change. It would be made up of four peninsular Spaniards and one from an overseas territory.

6 The text read: "Considerando que los vastos y preciosos dominios que España posee en las Indías no son propiamente colonias o factorías como los de otras naciones, sino una parte esencial e integrante de la Monarquía española ... se ha servido S. M. declarar que los reinos, provincias e islas que forman los referidos dominios deben tener representación nacional e inmedíata a su Real Persona y constituir parte de la Junta Central Gubernativa del Reino por medio de sus correspondientes diputados" (Whereas the vast and beautiful domains that Spain possesses in the Indies are not truly colonies or factories, like those of other nations, but rather an essential and integral part of the Spanish monarchy ... His Majesty has decided to declare that the kingdoms, provinces, and islands that make up the aforementioned domains shall have immedíate national representation to his Royal Personage and shall form part of the Central Governing Council of the Kingdom by means of their corresponding members of parliament). See the full text in Pi y Margall and Pi y Arsuaga 1902, 483-84.

7 Decree of 14 Feb. 1810.

8 Manuel González de Aguilar as Secretary of State and the Supreme Governing Council, Manila, 5 July 1810, Archivo General de Indias, the Philippines, 507, no. 11. Cited by Díaz-Trechuelo 1999, 446; Llobet 2011, ch. 4, provides an exhaustive study of how the election of the single representative from the Philippines was carried out and the plans of González de Aguilar in this respect.

9 This was the decree of 6 Oct. 1809, which complemented the previous royal orders from that same year in regard to the elections to the Cortes.

10 Some of the important data can be found in Philippine National Archives (PNA) 1807.

11 See Llobet 2010 and biographies of members of parliament in the Cádiz 2012 website (www. cadiz2012.es), Los diputados doceañistas, based on the work of García León 2012.
12 On creoles in the Philippines cf. Nolasco 1970; Joaquin 2005; Llobet 2011; Mojares 2006, 69-73, 201-5, 255-66, 289-337, 349-64.

13 "In accordance with the dictate of the Commission of Powers, the Cortes were approved by the representative from the city council of Manila, Mr. Ventura de los Reyes, member elected by the Philippine islands" (España Cortes Generales 1811, 2377). He joined the Cortes de Cádiz on 6 Dec. 1811. He remained a member of the Cortes until 10 May 1814, first as an elected member of the extraordinary Cortes, and then as a substitute until the arrival of the new members elected for the ordinary Cortes of 1813. Those representatives never arrived, as Ferdinand VII returned to the throne and nullified the Cortes de Cádiz. Congreso de los Diputados n.d.

14 España Cortes Generales 1812a, secret session.

15 The elimination of the galleon trade was established in article 3 of a decree on national trade as a whole, whose instructions had not yet been completed.

16 The terms were as follows: "Que se publique la supresión acordada de la nao de Filipinas, y que en su lugar pueda aquel comercio habilitar buques particulares a su costa para continuar su giro con la Nueva España al puerto de Acapulco, San Blas u otro de aquel reyno, según les acomode, baxo el mismo permiso de quinientos mil pesos concedido a dicha nao, y el millón de retorno, con la baja de la mitad de los derechos que paga, por no sufrir la hacienda nacional los gastos que erogaba con dicho buque, $\mathrm{y}$ libre de la pensión de boletas que gozan los cuerpos agraciados, cuyo importe se satisfará por la hacienda nacional" (That the elimination of the Nao de Filipinas that has been agreed upon be published, and in its place, merchant trade may assign private vessels, at its own expense, to continue the Nao's route to New Spain to the port of Acapulco, San Blas, or any other in that kingdom, at their convenience, applying the same permission of P500,000 granted to the Nao, and P1 million on the return, with a reduction by one half of the tariffs paid, as the national accounts do not incur the costs associated with the vessel, and free of the system of boletas enjoyed by the corresponding entities, which will be paid by the national treasury). España Cortes Generales 1813a, 4854. The proposal, although submitted several days earlier was read in the Cortes on 20 Mar. 1813.

17 The decree reads: "Primero, que se publique la supresión acordada de la Nao de Filipinas, y que los habitantes de aquellas islas puedan hacer el comercio de géneros de la China y demás del continente asiático con los puertos del mar del Sur de nuestras Américas, en buques nacionales por su cuenta, hasta en la cantidad total de un millón de pesos duros a su entrada en América, y extrayendo de ella el duplo en numerario. Segundo, que la Diputación provincial, oído el Consulado, arregle la distribución del millón de pesos que ahora se permite, con expresa exclusión de los cuerpos agraciados que hasta aquí fueron partícipes de esa gracia. Tercero, que se exijan por dicho comercio unos derechos moderados, tanto a la salida de géneros de Filipinas, como al dinero que entre en retorno. ... Cuarto y último, que el permiso para el millón de duros, y todo lo dispuesto para el comercio de efectos extranjeros del Asia se entienda provisional, pero que los frutos y géneros que son producto de aquellas islas sean perpetuamente libres al comercio con todas las demás provincias del imperio español" (First, that the elimination of the Nao de Filipinas that has been agreed upon be published, and that the inhabitants of those islands be allowed to engage in trade of goods from China and the rest of Asia with the ports of the Southern Sea of our Americas, on national ships, at their own expense, up to a total quantity of $\mathrm{P} 1$ million upon entry to America, and carrying from it with double that amount. Second, that the provincial Governing Council, in consultation with the Consulado [Trade Tribunal], arrange 
for the distribution of the P1 million that is now allowed, expressly excluding those entities that prior to this time enjoyed this privilege. Three, that in exchange for this trade, moderate tariffs be required on both outgoing goods from the Philippines, as well as the money that enters in return.... Fourth and finally, that the permission for the P1 million and all of the stipulations for the trade in foreign goods from Asia shall be understood as provisional, but that the goods and products that are produced by the islands shall be free for trade with all of the other provinces of the Spanish empire in perpetuity.)

18 Decree dated 14 Sept. 1813.

19 Decree dated 15 Oct. 1810. The original reads, "Que los dominios españoles de ambos hemisferios forman una sola y misma monarquía, una misma y sola nación, y una sola familia, y que, por lo mismo, los naturales que sean originarios de dichos dominios, europeos o ultramarinos, son iguales en derechos a los de esta península, quedando a cargo de las Cortes tratar con oportunidad y con particular interés todo aquello cuanto pueda contribuir a la felicidad de los ultramarinos."

20 The number of members varied: when the Cortes de Cádiz opened, on 24 Sept. 1810, there were just 104 members, of whom 47 were substitutes. The Constitution of Cádiz, ratified on 19 Mar. 1812, was signed by 184 members. When the Cortes de Cádiz opened on 14 Sept. 1813, there were 223 members, 47 of whom were substitutes. There is no unanimity in the sources or among authors in regard to the exact number of members.

21 The original reads: “En el día, cualquier noticia que se quiera mandar allá, no puede ser, porque ha pasado ya la época de salida de los buques, que es la de los meses de Febrero y Marzo. Si no ha salido la nao que se halla en Acapulco, lo podrá ejecutar en el mes de Noviembre y llegara a Filipinas a principios de Enero del año 13; las dificultades que allí ocurrirán para hacer las elecciones, por la navegación de monzones a que están sujetas las islas de Visasmo, ocuparán todo el 13; pero demos por supuesto que para principios del 14 se hallen los diputados en disposición de poder venir; deben salir por el mes de Enero, y llegarán aquí en el mes de Mayo, si hacen la navegación en derechura a éste punto, y si tienen que venir por la América no llegarán hasta Noviembre o Diciembre del año 14, tiempo en que ya se habrán concluido las Cortes de aquel año. Y así, es imposible que Filipinas pueda tener aquí diputación para el 13, y cuando más, a últimos del 14."

22 The original reads: "Debo hacer presente a V. M. que Las islas Filipinas cuentan 1.800 .000 almas, y que por consiguiente les tocan más de 25 diputados. Igualmente debo manifestar que dichas islas se hallan con extrema falta de fondos; $y$ que respecto que podrían estar representadas por uno o dos diputados, propuse que se les dispensara de la obligación de enviar todo el número que les corresponde, teniendo también en consideración el larguísimo viaje de 6.000 leguas que tienen que hacer los diputados de ellas, vengan por donde vinieren."

23 Ruth de Llobet 2011, in a still unpublished thesis with which I am acquainted, thanks to the author, develops this question in depth, opening lines of interpretation with regard to the role of the criollos in the political life of the Philippines in the early decades of the nineteenth century. Also, Mojares 2006 analyzes the tension between different Philippine groups through the study of the figure of Isabelo de los Reyes.

24 For this reason, the decision was made to include an additional article in the overseas instruction, which stated that "[e]n las islas Filipinas cuidará la Junta preparatoria, que se formará en Manila, de que si por las circunstancias particulares del país, o por penuria de los fondos necesarios para subvenir a los gastos de sus diputados, no pudieren enviar por ahora todos los que correspondan a su población, se envíen los que a juicio de aquellas provincias se crea conveniente" (In the Philippine islands, the preparatory Council, which will be formed in Manila, will, if due to the specific economic circumstances of the country, or lack of the funds required to pay the expenses of its representatives it is not possible to send all of the representatives that correspond to its population, be responsible for ensuring that the representatives who in its opinion are deemed necessary are sent). España Cortes Generales 1812c, 3191.

25 This is a key question for Philippine studies, although it is not the objective of this article, which is focused on discussions relating to the Philippines, raised in parliament at the time when Ventura de los Reyes was a member. Once again, for this question, I refer to the thesis of Llobet, 2011, who through a careful analysis of archival sources has done an excellent and fundamental work that explains the development of political life in the Philippines in the early decades of the nineteenth century, and how in those years were forged complicities that united creoles, natives, mestizos, and Chinese against the colonial regime. For the part that concerns this article, I can only add that Reyes did not bother to defend in the Cortes natives or Chinese, but his participation was more focused on defending the economic interests of those involved in trade of the islands, and on keeping power in the hands of the creoles, than on protecting the rights of all the inhabitants of the archipelago.

26 The new governor-general of the Philippines, José de Gardoqui, was forced to publish an edict on 8 Feb. 1814, which explained that it was necessary to continue contributing to the support of the state through the tribute.

\section{References}

Aguilar, Filomeno Jr. 1998. Clash of spirits: The history of power and sugar planter hegemony on a Visayan island. Quezon City: Ateneo de Manila University Press.

Alonso, Luis. 2009. El costo del imperio asiático. La formación colonial de las islas Filipinas bajo el dominio español, 1565-1800. México: Instituto Mora, Universidade da Coruña.

Artola, Miguel, ed. 2003. Las cortes de Cádiz. Madrid: Marcial Pons.

Aymes, Jean-René. 2008. La guerra de la independencia en España (1808-1814). Madrid: Ed. Siglo XXI

Castellanos, Alicia. 2012. Representantes de Filipinas en las Cortes de Cádiz. In La Constitución gaditana de 1812 y sus repercusiones en América, ed. Antonio Gutiérrez Escudero, vol. 1. Cádiz: Universidad de Cádiz.

Celdrán, Julia. 1994. Instituciones hispano-filipinas del siglo XIX. Madrid: Ed. Mapfre.

Chust, Manuel. 2010. América en las Cortes de Cádiz. Madrid: Fundación Mapfre-Doce Calles.

Chust, Manuel and Ivana Frasquet. 2012. La patria no se hizo sola: Las revoluciones de independencias iberoamericanas. Madrid: Silex Ediciones.

Congreso de los Diputados. N. d. Reyes, Ventura de los. In Archivo histórico de diputados, 1810-1977. A. C. D. Serie Documentación Electoral 3 no. 16, 5 no. 24. Online, http://www.congreso.es/portal/ page/portal/Congreso/Congreso/SDocum/ArchCon/SDHistoDipu/, accessed 2 Aug. 2013. 
Cullinane, Michael. 1981. The changing nature of the Cebu urban elite in the 19th Century. In Philippine social history: Global trade and local transformations, ed. Alfred McCoy and Ed. de Jesus, 251-96. Quezon City: Ateneo de Manila University Press.

2003. Ilustrado politics: Filipino elite responses to American rule, 1898-1908. Quezon City: Ateneo de Manila University Press.

Cushner, Nicholas. 1971. Spain in the Philippines: From conquest to revolution. Quezon City: Institute of Philippine Culture, Ateneo de Manila University.

Díaz-Trechuelo, Ma. Lourdes. 1999. Filipinas ante la independencia de la América continental. José Martí y su tiempo, ed., Luis Navarro, 440-57. Sevilla: Universidad de Sevilla-Fundación El Monte.

. 2001. Filipinas, la gran desconocida (1565-1898). Pamplona: Ediciones Universidad de Navarra, S. A.

España Cortes Generales. 1811. Diario de sesiones de las Cortes generales y extraordinarias, sesión del día 6 de Diciembre: 2377-83.

_. 1812a. Diario de sesiones de las Cortes generales y extraordinarias, sesion del día de 11 de Febrero: 2755.

___ 1812b. Diario de sesiones de las Cortes generales y extraordinarias, sesion del día de 5 de Mayo.: 3147-60.

—. 1812c. Diario de sesiones de las Cortes generales y extraordinarias, sesion del día de 18 de Mayo: 3189-92.

- 1813a. Diario de sesiones de las Cortes generales y extraordinarias, sesion del día de 20 de Marzo: 4851-54.

- 1813b. Diario de sesiones de las Cortes generales y extraordinarias, sesion del día de 25 de Marzo: 4875-85.

—. 1813c. Diario de sesiones de la Cortes generales y extraordinarias, sesión del día de 29 de Marzo: 4907-21.

Fenner, Bruce Leonard. 1985. Cebu under the Spanish flag, 1521-1896: An economic-social history. Cebu City: San Carlos Publications.

Fernández Sebastián, Javier. 2012. La aurora de la libertad. Madrid: Marcial Pons.

Fradera, Josep M. 2005. Colonias para después de un imperio. Barcelona: Editions Bellaterra.

- 2008. La nación desde los márgenes: Ciudadanía y formas de exclusión en los imperios. Illes i Imperis 10-11:9-30.

Gálvez, Juan. 1812. Sesión de las Cortes de Cádiz, c. 1812. Tinta y aguada sobre papel. Fundación Lázaro Galdiano, Madrid, Inv. 7476. Online, http://www.bne.es/es/Micrositios/Exposiciones/America/ Exposicion/Seccion2/Obra14.html?origen=galeria, accessed 8 Aug. 2013.

García León, José Ma. 2012. Los diputados doceañistas: Una aproximación al estudio de los diputados de las Cortes generales y extraordinarias (1810-1813), 2 vols. Cádiz: Quorum.

Joaquin, Nick. 2005. A question of heroes. Pasig City: Anvil.

Legarda, Benito Jr. 1999. After the galleons: Foreign trade, economic change and entrepreneurship in the nineteenth-century Philippines. Quezon City: Ateneo de Manila University Press.

Llobet, Ruth de. 2009. El poeta, el regidor y la amante: Manila y la emergencia de una identidad criolla filipina. Istor: Revista de Historia Internacional 38:65-92.
2010. Ventura de los Reyes. In Diccionario biográfico de los parlamentarios españoles, Cortes de Cádiz, 1810-1814. Madrid: Cortes Generales.

_ 2011. Orphans of empire: Bourbon reforms, constitutional impasse, and the rise of Filipino Creole consciousness in an age of revolution. PhD thesis, University of Wisconsin-Madison.

Lorente, Marta and José María Portillo. 2011. El momento gaditano. La Constitución en el orbe hispánico (1808-1826). Madrid: Congreso de los Diputados.

Malamud, Carlos, coord. 2012. Ruptura y reconciliación. España y el reconocimiento de las independencias latinoamericanas. Madrid: Taurus.

Martínez Shaw, Carlos and Marina Alfonso Mola, eds. 2000. El galeón de Manila. Madrid: Ministerio de Educación, Cultura y Deporte.

Mojares, Resil. 2006. Brains of the nation: Pedro Paterno, T. H. Pardo de Tavera, Isabelo de los Reyes and the production of modern knowledge. Quezon City: Ateneo de Manila University Press.

Nolasco, Clarita. 1970. The creoles in Spanish Philippines. Manila: Far Eastern University.

Philippine National Archives (PNA). 1807. Protocolos de Manila, 45, 1807, Tomo 1, 2. Notary M. del Castillo. Will and testament of Ventura de los Reyes, 19 Jan. SDS 19810.

Pi y Margall, Francisco and Francisco Pi y Arsuaga. 1902. Historia de España en el siglo XIX, vol. 1. Barcelona: Segui.

Piqueras, José Antonio. 2010. Bicentenarios de la libertad. La fraqua de la política en España y las Américas. Barcelona: Península.

Portillo, José Ma. 2006. Crisis Atlántica: Autonomía e independencia en la crisis de la monarquía hispana. Madrid: Marcial Pons.

Schurz, William. 1939. The Manila galleon. New York: E. P. Dutton.

TePaske, John H. 1983. New World silver, Castille and the Philippines, 1590-1800. In Precious metals in the later medieval and early modern world, ed. John F. Richards, 425-46. Durham: Carolina Academic Press.

Yuste, Carmen. 1984. El comercio de la Nueva España con Filipinas, 1590-1785. México DF: Instituto Nacional de Antropologia e Historia, Departamento de Investigaciones Históricas.

2007. Emporios transpacíficos. Comerciantes mexicanos en Manila 1710-1815. México: Universidad Nacional Autónoma de México.

María Dolores Elizalde is Investigadora Científica at the Institute of History, Center of Human and Social Sciences, National Center for Scientific Research (Consejo Superior de Investigaciones Científicas or CSIC), Albasanz 26-28, 28037 Madrid, Spain. The head of the Line of International Studies, she specializes in International History and in Colonial and Postcolonial Processes in Asia and the Pacific in the nineteenth century. Among more than seventy publications, she is author and editor of the following volumes: España en el Pacífico: La colonia de las islas Carolinas, un modelo colonial en el contexto del imperialismo (1992); Imperios y Naciones en el Pacífico (2001); Las relaciones entre España y Filipinas, siglos XVI-XX (2003); Repensar Filipinas, Política, Identidad y Religión en la construcción de la nación filipina (2009); Filipinas, un País entre dos Imperios (2011); Nacionalismo versus Colonialismo en el Sudeste asiático. Problemas en la construcción nacional de Filipinas, India y Vietnam (2013). <lola.elizalde@cchs.csic.es> 